\title{
The Image of Germany in Social Media: Political and Social Aspects of Public Service Media in Poland
}

\author{
Agnieszka Węglińska \\ ORCID: 0000-0002-2573-5981 \\ UNIVERSITY OF LOWER SILESIA, POLAND
}

https://doi.org/10.19195/1899-5101.13.1(25).4

\begin{abstract}
The goal is this paper is to analyze the image of Germany and Germans in social media platforms of Polish Television (Telewizja Polska - TVP). Through a web content analysis the study aims at presenting main societal and political aspects in the daily functioning of public service media. The outcome is therefore presented in a broad social and historical context, including relations between Germany and Poland. The main factors shaping bilateral relations such as stereotypes, trans-border cooperation and the presence of the German minority in Poland are presented. The empirical part of the paper comprises content and discourse analysis of TVP' s social media related to the image of Germans and Germany over a period of three months in 2018.
\end{abstract}

KEYWORDS: TVP, Germany, social media, an image, content analysis, discourse analysis.

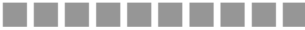

\section{INTRODUCTION}

Creating an image of a foreign person is always complicated, particularly when a neighbouring nation is being considered. Poland and Germany have a common history of wars, cooperation, alliances, diplomacy, and economic collaboration. PolishGerman history has been determined by contentious bilateral issues as well as problems that stem from the Partitions and German aggression in 1939. It is worth mentioning that most of the time Polish-German relationships were characterised by profitable coexistence and economic cooperation. Moreover, the Polish-German border was the safest in the region between the 16th and 18th centuries (Matelski, 2017). The Partition of Poland by Prussia, Austria, and Russia at the end of the 18th century and the loss of independence indicates a turning point in the Polish-German relationship. It seems that the last two centuries cast a shadow over PolishGerman relations (Matelski \& Sakson, 2013). The situation has improved since 1989, when Poland returned to a democratic system. 
The image of a neighbouring country depends on various factors such as history, politics, economy, culture, and media. Moreover, this phenomenon seems very changeable. In the paper, three elements are being considered: the image of Germany and Germans in social and political aspects, the remit of public service media, as well as social media as a platform to maintain stereotypes. It is also worth noting that stereotypes are not the only factor that contribute to the creation of the image of Germany. German minorities in Poland might be considered as a carrier of the image in the region inhabited by Germans (Trzcielińska-Polus, 2016; Ganowicz, 2016; Olechowska, 2017).

In Polish media, Germany has always been a very attractive topic. The image of Germans and Germany is shaped in Polish society by certain social, political, economic, and historical factors. The research of the media agenda shows that controversial topics, particularly those related to the neighbouring nation - the nation defined as the centre (Díez-Nicolás, 2009), are the most interesting to a wide-ranging audience. There are numerous studies on Germany and the image of German people in the Polish literature. However, they mainly concentrate on the press content and public opinion (Ociepka et al., 2009; Röger, 2009; Hess \& Szymańska, 2009; Nowicka, 2010; Olechowska, 2015; 2017). Public service media in Poland has been recently politicized by The Law and Justice party (PiS), which has been in power since 2015. The creation of the image of the 'bad German' has become a tool for the ruling party in its political fight.

The goal of this study is to examine the image of Germany in the context of stereotypes and the remit of public service media. The Author presents the content and discourse analysis of Polish Television (Telewizja Polska - TVP) social media on the image of Germany in a three months time. Two consecutive parts of the paper are devoted to the presentation of studies and opinion research on the image of Germans and Germany in a social and political context. To this end, the paper presents results from quantitative and qualitative research.

\section{GERMANY-POLAND RELATIONS}

Stereotypes have played an important role in the history of Polish-German neighborhood. Stereotypes can be defined as characteristics associated with certain political and social categories. Stereotypes help people organize and understand their social environment (Allik, Mõttus, \& Realo, 2010; Realo et al., 2009; Terracciano et al., 2005). Stereotypes can contribute to ungrounded negative attitudes. At the same time, they can simplify reality and help explain the environment. However, they can also project a false the picture of the world. The best way to break stereotypes is via the mutual contact (Kania \& Jasińska, 2001). National stereotypes function at different levels of consciousness of an ethnic group. They can be found in media also at the level of spoken tradition, for instance in phraseology (Kurcz, 2008). 
Relations between Poland and Germany are complex. Germany is a powerful state, while Poland is an aspiring country with the aim of improving its relative standard of living and increasing its economic potential in the region. These complex relations were reinforced during the period of The Polish People's Republic, through Polish waves of economic migration in the 1970s and 1980s. The disparity between Poland's economic crisis and German prosperity was indisputable and provoked bitter reflection towards the real result of the Second World War (Wóycicki \& Czachór, 2009). Therefore, strong stereotypes, such as alien or an enemy - aggressor (Dąbrowski, 2009) have widely developed. The colonizer stereotype can be explained by the centre - periphery approach (Díez-Nicolás, 2009). From this perspective, Germany is perceived as a centre - dominant player in Europe contrary to Poland - a periphery country. In the context of the centre - periphery theory, the main role in upholding negative stereotypes can be the paternalistic attitude on the German side and inferiority complex on the Polish side (Wóycicki \& Czachór, 2009).

A new chapter in Polish-German relationships began in 1989 with the Solidarity movement's victory in Poland and the collapse of the communist system. Germany supported Poland's efforts to obtain NATO and EU membership during that time and economic and cultural cooperation between the two neighbours grew. In post-war relationships between Poland and Germany the following periods can be identified: (1) the decline of a Cold War ideology; (2) a period of improving bilateral relations; (3) collaboration in the European Union; (4) stable relationships between Poland and Germany despite complications; (5) a deterioration in Polish-German relations since 2015.

The political and economic issues affect public opinion. Figure 1 illustrates the distribution of the opinion of Poles on relations with Germany.

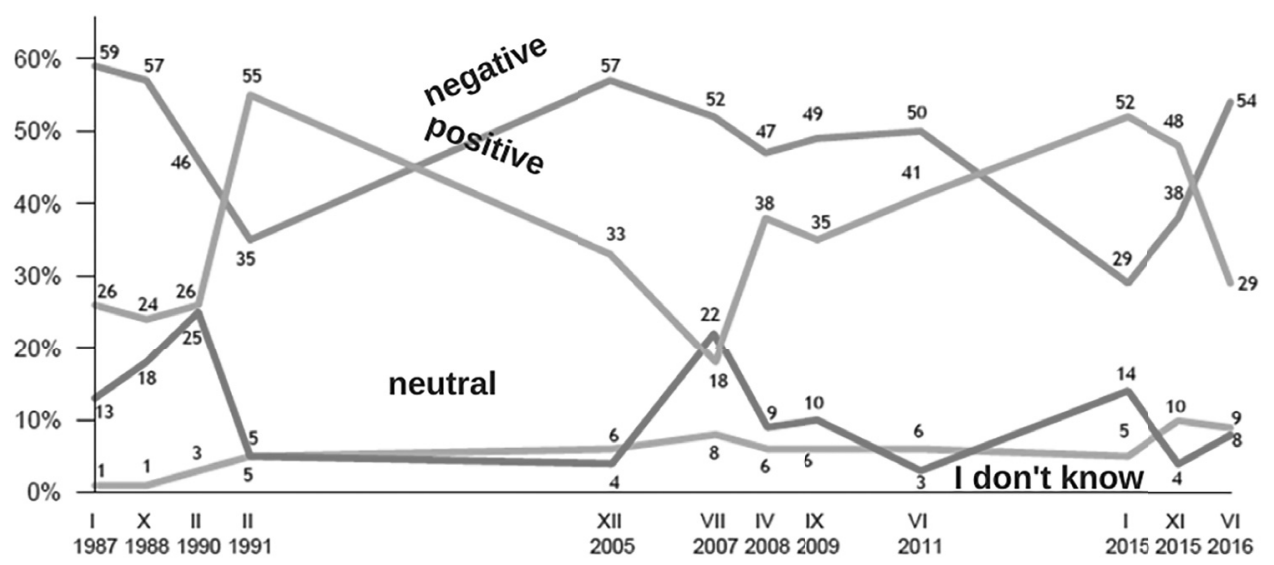

Figure 1. Poles' opinions of Germany, findings from public opinion research

Source: CBOS (2016). 
The significant increase in negative opinions about Polish-German relations was noticed in 2005. The main reason was the agreement between Gerhard Schröder, Chancellor of Germany and Vladimir Putin, the president of Russia, regarding the construction of Nord Stream - a North European Gas Pipeline (CBOS, 2016). The second reason was the anti-German rhetoric by the Law and Justice Government (2005-2007) which returned to power in 2015. The second Law and Justice Government raised the rhetoric of Second World War reparations. The discussion concerns reparations made after the war by the vanquished to the victors. However, communist Poland resigned from war reparations from Germany in 1953. The research of Centre of Public Opinion Analysis (TNS Poland, 2014) evidenced that reconciliation between the two nations is regarded impossible for $40 \%$ of Poles. However, the possibility of mutual forgiveness noted by $53 \%$ of Poles is an optimistic fact (TNS Poland, 2014).

In the contexts of post-war rhetoric and centre-periphery theory, the image of Germany has often been negative. On the other hand, in the trans-border regions, such as Opole and Silesia, Germany is seen a partner (Olechowska, 2015). Data about stereotypical image of Germans and Germany identify both positive and negative attitudes. In the foreground, the list of positive features includes being organized, disciplined, and punctual. The list of negative stereotypes includes features like arrogance or pride (CBOS, 2015).

\section{THE IMAGE OF GERMANY IN THE POLISH MEDIA}

Media play an important role in shaping stereotypes and prejudices in Polish-German relations. Various reports from different public opinion centres indicate that Poles receive their information about other cultures and nations from television. Research by Piontek (2011) provides an overview of journalism and media in contemporary Poland. In 2009 and 2010 Piontek compared the content of two news programmes: "Wiadomości" TVP (public service media) and "Fakty" TVN (private broadcasting). The research concluded that the level of tabloidization in both private and public service media can be defined as high (Piontek, 2011). In addition to this, there have been significant studies of journalists' roles in society (Hess \& Szymańska, 2014) and journalistic activities via social media (Łokić, 2014). Researchers have also evidenced the tabloid nature of social media (RISJ, 2016). The tendency of media tabliodization is manifested in trends to present contrasting content, negativism, pictogram messages, dominance of soft news, and so on (Sparks, 2000).

On the other hand, public media in Poland have recently evolved towards state media, with close ties between journalism and politics. The communist past has been seen as one of the reasons why journalists at TVP respond to political pressure. In fact, both decision-makers and public service media authorities lack a basic understanding of the public interest, public service, the remit of the public broadcaster and the public objectives (Węglińska, 2018). Due to the high level of polit- 
ical parallelism, public service media in Poland reflect the goals of the ruling government. Jarosław Kaczyński, leader of the Law and Justice party, has made several contributions on Germany and German citizens. In his opinion, Germans are rich, strong, and they cooperate with Russia. According to populist ruling party rhetoric, Poles should not trust Germans, even though they are Polish allies.

In the last couple of years, transformation of Polish-German rhetoric was followed by the increasing dependency of TVP on the government (Wąsicka-Soroczyńska, 2019). TVP has also recently developed its online services, and extended its activities via social media (Węglińska, 2018). In 2018 in the context of the 100th anniversary of Polish Independence, the discussion concerning the German role in creating a Polish national identity was back on the agenda. Additionally, the topic of Nord Stream 2 has returned to political public debate, however in a new dimension.

Media studies in Poland have already identified the image of Germans and Germany from a printed press content perspective (Ociepka et al., 2009). Researchers looked at the tabloid "Fakt" (Röger, 2009), the daily newspaper "Gazeta Wyborcza" or weekly magazines, such as "Polityka" (Nowicka, 2010). However, there is a lack of research regarding audio-visual media and their content published online.

\section{TVP AND SOCIAL MEDIA}

\section{Methodology and hypotheses}

Research on the image of Germany on social media of TVP was conducted by web content analysis with two research techniques: content analysis and the coding frame. This study draws on the code book and an analytic tool for social media monitoring developed by Brand24 (brand24.pl).

The following research hypotheses were formulated:

H1: Polish Television (TVP) upholds in social media negative stereotypes of Germany.

H2: The negative image of Germany is related to the policy of the ruling Law and Justice party.

H3: The image of Germany can be related to the region of a particular local TVP station.

The following research questions were addressed:

RQ1: Are the negative stereotypes of Germany being maintained on TVP social media?

RQ2: Which elements of the image of Germans and Germany are dominant in TVP social media? 
RQ3: Is the dominant image of Germans and Germany in TVP social media related to the ruling party ideology?

RQ4: Do the dominant stereotypes of Germans and Germany on TVP social media's agenda relate to an anti-German or anti-immigrant rhetoric of the ruling party?

Web content analysis with elements of discourse analysis was conducted in the period of June 30,2018-September 28, 2018. The study included several social media platforms, such as Facebook, Twitter, video profiles of TVP (and TVP info), as well as several programmes and official profiles of TVP journalists. The research material comprised of 395 mentions of the following keywords: German, Germany, Merkel. The inclusion of September 1 - the anniversary of Nazi Germany's attack on Poland in 1939 - was important in the choice of the analyzed period. In the background of mentioned events is the 100th anniversary of Polish Independence. This anniversary makes the year 2018 crucial in the context of Polish-German relations. Overall, the research frame allowed us to evidence the image of Germany with a focus on particular events, such as: the 2018 FIFA World Cup; resignation of Horst Seehofer, Germany's interior minister, due to German immigration policy (July 2, 2018); the NATO summit in Brussels (July 11-12, 2018); Trump-Putin summit in Helsinki (July 16, 2018); European Athletics Championship in Berlin (August 8-12, 2018); Merkel-Putin working meeting (August 17, 2018); the anniversary of Nazi Germany's attack on Poland (September 1, 2018); Merkel-Schetyna (opposition leader) meeting (September 24, 2018).

\section{Quantitative research}

Figure 2 presents the results of the quantitative study. The most active in terms of the image of Germany were TVP's accounts on Facebook. However, Twitter was seen as the main channel when looking at social media activities of TVP Info (a 24hour news channel). This might be due to the fact that Twitter concentrates on real-time communication and is a useful source for news journalism (Harrington, 2014; Navar-Gill, 2017). The wide use of Facebook can be explained by young audiences' behaviors (Keib \& Wojdynski, 2017).

People express their opinions in different ways, and analyzing the sentiment in a sentence is difficult to measure via statistical approaches. The goal of sentiment analysis is to verify the sentiment orientation (i.e. positive, negative or neutral) by analyzing sentiment or opinion words and expressions in sentences (Bohlouli et al., 2015). Therefore, all mentions were further analyzed by sentiment perspective. The tool by Brand 24 has the function of classification of the sentiment score. My research combines content analysis with contextual analysis in order to give a rounded perspective to the study of the image of Germany. Such a perspective takes into consideration simultaneously the text (the linguistic), and their socio-political, 


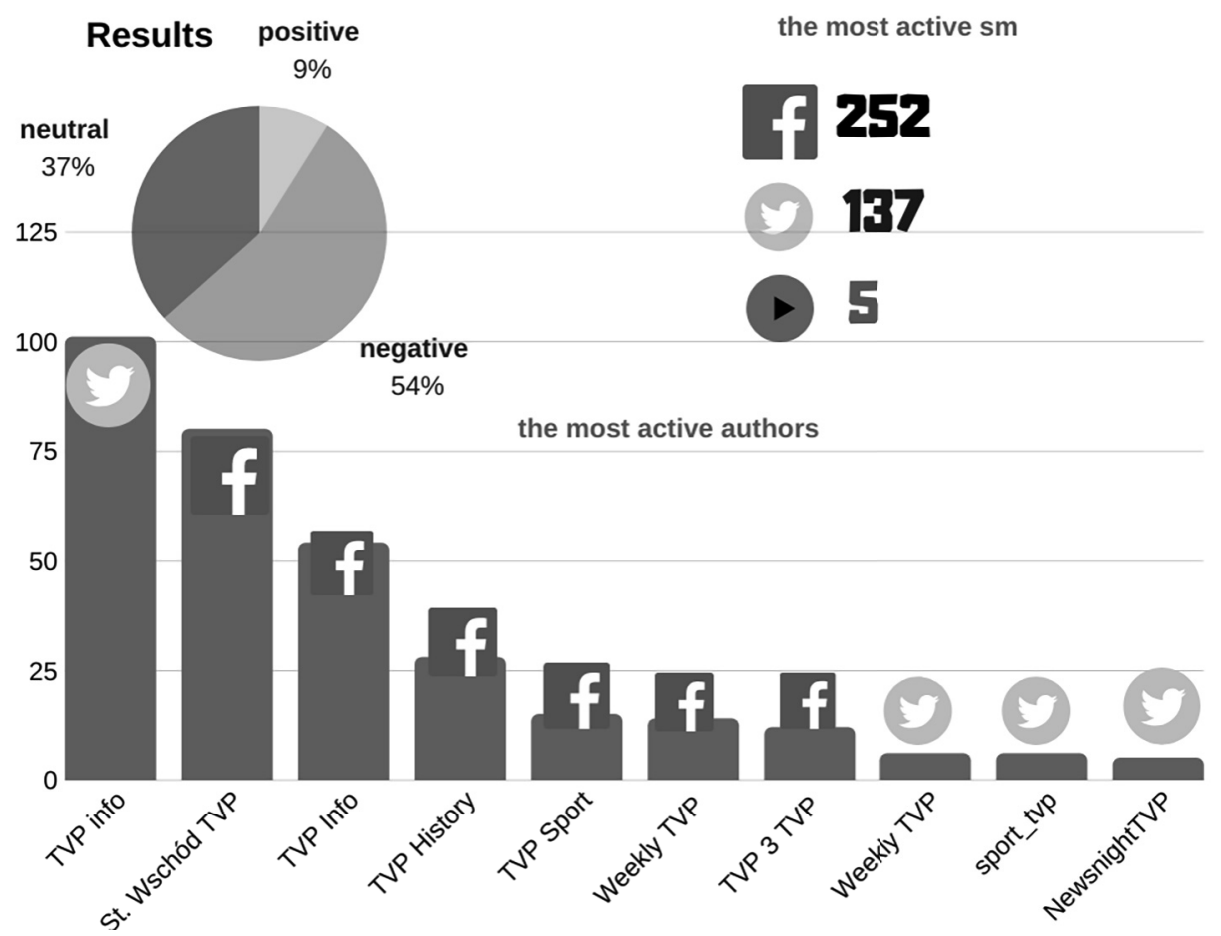

Figure 2. Results from quantitative research

Source: Author, Brand24.

historical, and social context of news. Moreover, context interpretation is always marked by subjectivity (Van Dijk, 2006; 2009; Trimithiotis, 2017). Overall, 54\% of mentions were classified as negative, while only $9 \%$ had positive connections. In addition to this, $37 \%$ of mentions were classified as neutral (Figure 2).

\section{Qualitative research}

In the course of qualitative analysis six categories of mentions were distinguished (Figure 3):

1) the aggressor - The Second World War, German invader, Nazi, the enemy, SS soldier, the admirer of Hitler, a murder, the peak;

2) the colonizer - the alliance with Russia, does not observe the law itself, but at the same time accuses Poland - a hypocrite, despises Poland, a country one cannot trust, the 'old invader', a country interested in cooperation with Russia against Poland (Nord Stream)' the intensity of mentions appearing in this category increased during the Helsinki summit and meeting of Merkel and Putin;

3) a rich country - an important player in the world of politics and economics, a leading country in the EU, an economic partner for Poland, a big investor in 
Poland, an employer, the main European player in the world, Angela Merkel — 'the Queen of Europe'; the peak days for this category was during the NATO Summit.

4) a neighbouring country - a neighbouring country mentioned with regard to cooperation, organization of events, students' and employees' exchanges; the intensity of mentions in this category was rather divided;

5) the German minority - 'the next-door neighbours' in the regions of Opole and Silesia, friendships, regional politicians, the intensity of mentions in this category was rather divided with a peak on August 22 - the announcement of German minority candidates to regional/municipality councils.

6) A country of refugees - mentions that comprised topics such as immigrant problems in Germany, aggressive Muslims in Germany, acts of terrorism in Germany. The distribution of mentions in this category was rather divided, the peak day was July 2, 2018, which marked the resignation of Horst Seehofer.

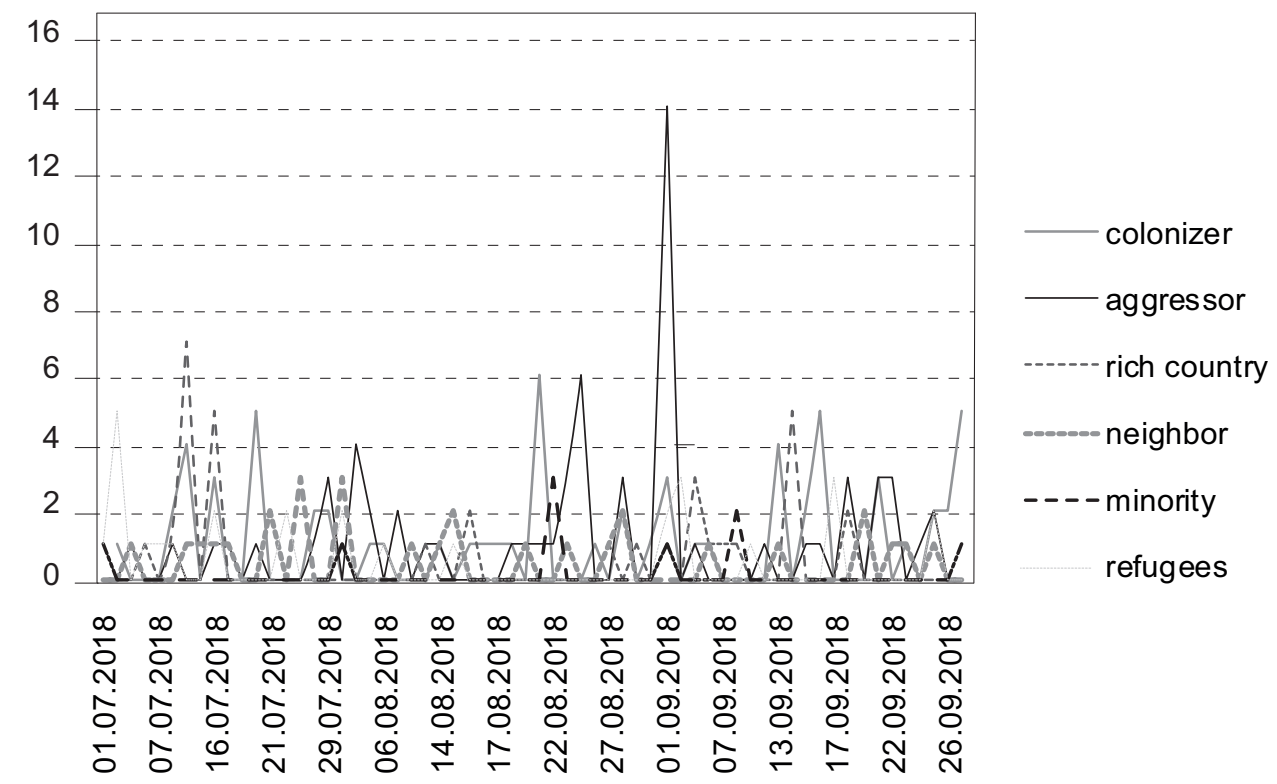

Figure 3. The intensity of mentions in six key categories

Source: Author, Brand24.

Figure 4 further illustrates the distribution of positive, negative, and neutral mentions in three categories related to the main stereotypes. The category of the neighbouring country had the largest number of positive and neutral mentions. The most influential authors in this category were TVP info on Twitter and Facebook, TVP Sport on Facebook, as well as regional TVP stations from transborder regions - TVP Gorzów Wielkopolski, TVP Szczecin, TVP Opole on Facebook. One of the examples of mentions from this category is presented below: 
25 years have passed. The Spree-Neisse-Bober Euroregion celebrates its jubilee. Polish and German communities cooperating with each other in the field of environmental protection, education, and tourism (TVP Szczecin).

The mentions concerning cooperation with the neighbouring country contain joint sporting events or educational initiatives. What is more, Polish-German cross-border business cooperation, social phenomena, or cultural events in Germany were also mentioned in this category. The other category where the distribution of positive, negative, and neutral mentions was almost equal was the connotation of the 'rich player'. In this category, TVP info and TVP Sport were the most active and influential authors on TVP's social media. This category included mentions about German international activities, such as diplomatic visits of Angela Merkel, but also comments and analyses after the 2018 European Athletics Championships in Berlin. In this category, Germany was seen as a country which Poland is supposed to follow. Germany should be considered an ally of Poland. Furthermore, Germany is a positive role model, as illustrated below:

Poland is in the top 25 most-developed economies in the world. We are in the same group as the USA, Japan and Germany (TVP info).

However, during the time of the NATO summit in Brussels, the topic of Germany appeared mostly in negative meanings (see Figure 4). Polish public media journalists accused Germany of avoiding an increase to $4 \%$ of their spending to the NATO budget. The largest number of negative mentions was attributed to a code 'colonizer'. This data evidenced an image of Germany as an aggressive country, which 'has been colonizing Poland' in political and economic terms. This kind of image has its roots in times dating back to Poland's partitions. The category of the colonizer is related to the official rhetoric of the ruling Law and Justice party. The characteristic feature for Law and Justice leaders' narrative is that of a general antiGerman attitude. According to the party's programme, the ambition of Poland shall be to create a counterbalance to Germany in Europe. Law and Justice has been trying to give the impression of an equal and strong partner for Germany in Europe (Batory Foundation Report, 2017). However, the crucial element of this strategy has been to constantly recall the German colonizer past:

The new German order of the world - the Minister of International Affairs - Heiko Maas' diplomacy outlined the new European Union. A united and sovereign union. A union without nation states - a German Union. Heiko Maas met minister Jacek Czaputowicz several days ago (Studio Wschód TVP).

The construction of the Nord Stream 2 gas pipeline, which will connect Russia and Germany, was one of the topics discussed by Andrzej Duda and Donald Trump in the White House. President Donald Trump strongly opposes construction of Nord Stream 2 (TVP Info). 
As illustrated above, some mentions can be interpreted as a German attempt to restore a traditional alliance with Russia against Poland. In addition to this, in some mentions references to the Yalta Treaty were used in the context of the Helsinki Summit. The most active author in this category was TVP's Info news programme Studio Wschód (Studio East) on Facebook, with a significant role of Twitter in the case of TVP Info.

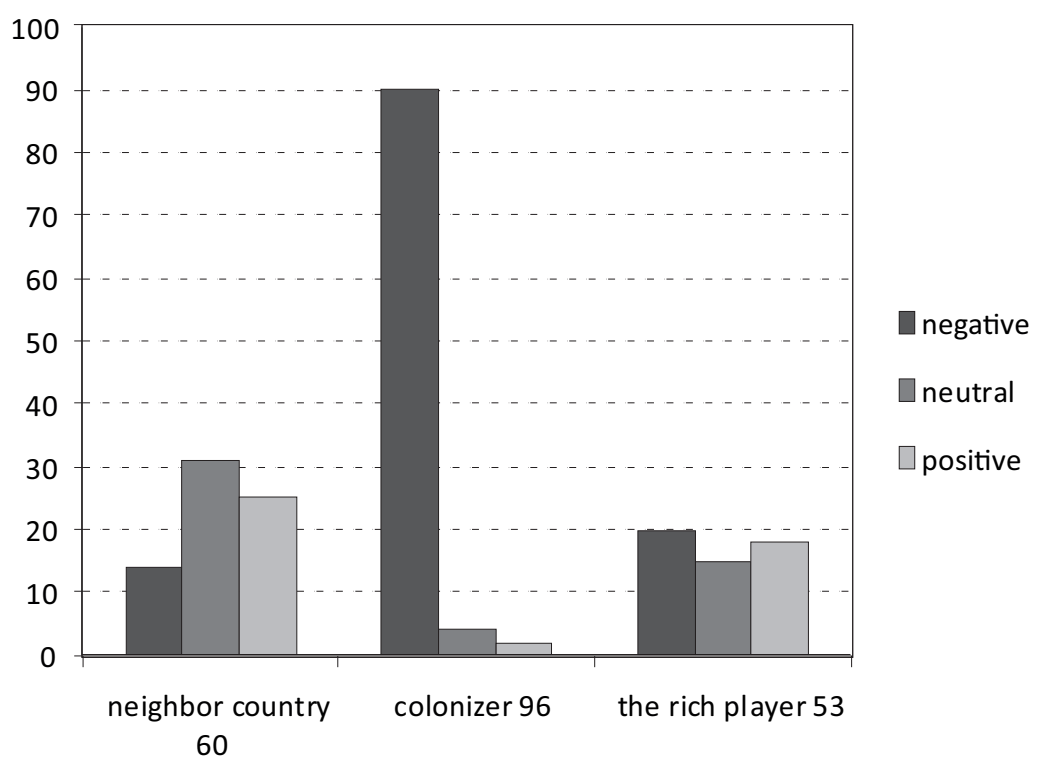

Figure 4. Findings from qualitative research (1)

Source: Author, Brand24.

The category of aggression was indicated as stronger than colonizer. The foreground of this frame was the Second World War and the German invasion of Poland. In this category the historical context was the most important and was further associated with the image of aggressor, Nazi and murder. Figure 5 indicates the number of mentions on TVP's social media. One of the most active authors in this frame was TVP History - a thematic channel on history. Moreover, this category was represented by mostly negative mentions which mostly reflected Polish fears of Germans and upholds negative stereotypes of the Nazi period. Similarly to this, TVP's social media on September 1st were full of cruel stories from the war:

The Golgotha of Polish villages — we are talking about Michnikowo, Świętokrzyskie, where 75 years ago, Germans murdered the residents because they fought for a free Poland and helped Polish soldiers. It was there - for the first time - that a new public holiday was established - the Day of the Fight and Martyrdom of the Polish Village (Panorama TVP/ Facebook). 
The category of 'country of refugees' appeared mostly as negative mentions. From May 2015 there has been an increase in the percentage of Poles who oppose accepting refugees from the areas affected by armed conflict. However, the majority of the Polish population (54\%) supported the provision of assistance to people from war regions, though usually only until the end of the conflict in the country of origin of refugees (46\%) (CBOS, 2016). TVP made many mentions which blamed Angela Merkel for the refugee crisis. The peak day for this category was July 2nd, 2018 with a story about the government crisis in Germany. Its goal was to mark the responsibility of Angela Merkel for the situation and forecast consequences in the future - the breakdown of the coalition between the CDU/CSU:

The government crisis in Germany. This is the biggest political crisis in Germany in recent years. Chancellor Angela Merkel loses not only support, but also credibility. Bavarian CSU sets the condition: tightening migration policy or the breakdown of the government, but the German Chancellor does not intend to admit to her mistakes (TVP Info).

TVP social media presented Germany as a country which gives support to Muslim immigrants seen as extremists, terrorists, and rapists etc.

The German police is looking for 126,000 illegal immigrant criminals. The German police is looking for hundreds of thousands of people - the Federal Criminal Office indicates a large number of migrants avoiding deportation (TVP Info).

The most influential and active social sites in this category were the social media of TVP Info. Social networks mostly upheld the negative image of Germany as a country with a refugee crisis. The problem of migration was simplified, tabliodised and therefore maintained several stereotypes.

The category of the German minority in Poland was measured with a case study of a regional television station, TVP Opole. In this case only 10 mentions which comprised information about the German minority were included in the final dataset. The most active and most influential TVP channel was TV Opole on Facebook. The peak day for this category was on August 22nd, 2018 when the German minority introduced their candidates to regional/municipal governments. Mentions in this category were mostly neutral or positive:

The German minority today officially announced the start of the election to regional government. At the press conference their activists presented the electoral slogan and the leading candidates in 4 out of 5 districts elections to the regional council (TVP Opole).

The negative mentions in this category concerned the speech of Jarosław Kaczyński, who warned of cooperation of the German minority with Germany against Poland. 


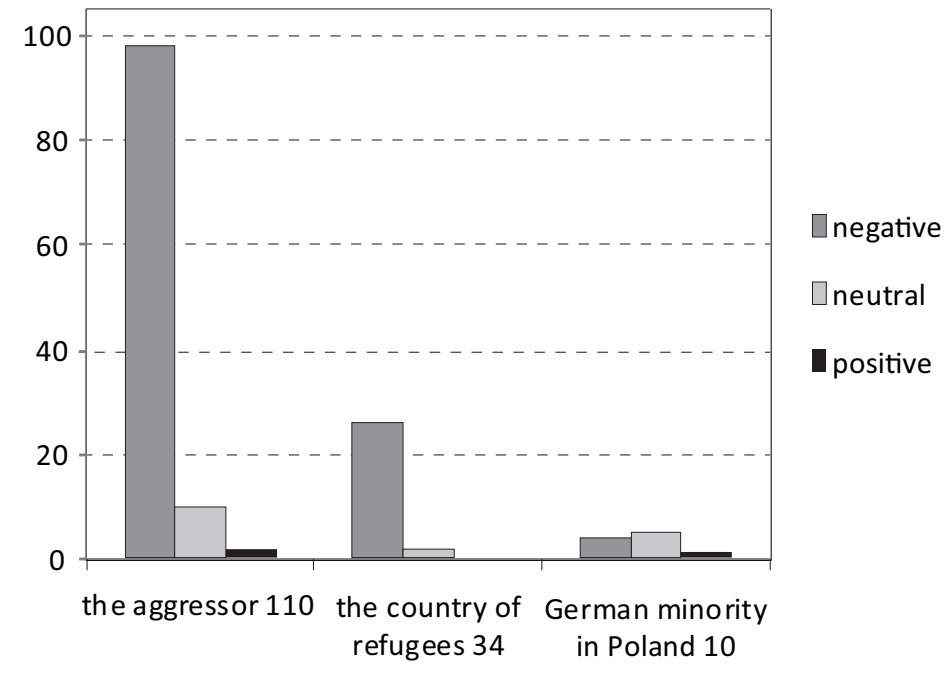

Figure 5. Findings from qualitative research (2)

Source: Author, Brand24.

\section{CONCLUSIONS}

The research has shown that the dominant stereotypes of Germany, such as aggressor, colonizer, a neighbouring and rich country are maintained in TVP social media. In the majority of cases public service media in Poland uphold the negative image of Germans and Germany. The majority of the analyzed mentions were negative (H1). Furthermore, the content provided in TVP's social media was related to the governing party policy (H2). The image of Germans and Germany as the historical enemy was often used by Law and Justice leaders. The members of Law and Justice often recalled the example of Germany to explain anti-immigrant statements. In addition, September 1st activities on social media have proven that the historical background is still a key factor in shaping the image of Germany in TVP. The dominant stereotypes of Germans and Germany - as an aggressor and colonizer built on the position of Germany in the past and in contemporary Europe.

Germany was presented on social media in the context of The Second World War, Nord Stream cooperation, European economy, and collaboration with the EU. The most expansive and negative categories of TVP's social media were that of aggressor and colonizer. The context of the aggressor comprised several components, including the Nazi attack in 1939, the Ribbentrop-Molotov Pact, the Holocaust, and Adolf Hitler's propaganda. The context of the colonizer was built mostly in the context of economics (RQ2). Positive and neutral stereotypes of Germans and Germany occurred most often in the context of the German football team, German minorities (Opole and Silesia), neighbour, employer, EU partner and a role model 
for Poland (RQ1). The negative image of Germany was used by the ruling Law and Justice party to justify its political ideology and activities. Law and Justice's official rhetoric is built on anti-German elements. Government control over TVP contributes to public service media being a tool for propaganda and politics (R3). TVP used social media to reach young audiences (RQ4). Additionally, the tendency of social media to create contrasting and unequivocal massages fostered the negative image of Germany.

\section{REFERENCES}

Allik, J., Mõttus, R., \& Realo, A. (2010). Does national character reflect mean personality traits when both are measured by the same instrument? Journal of Research in Personality, 44, 62-69.

Analysis of the Relation Between and Impact of Public Service Media and Private Media (2016). The Reuters Institute for Study of Journalism (RISJ), Oxford, Retrieved March 11, 2017, from http:// reutersinstitute.politics.ox.ac.uk/publication/analysis-relation-between-and-impact-publicservice-media-and-private-media.

Attitudes towards refugee in Poland and Czechia (2015). CBOS Survey, Retrieved June 15, 2018, from http://www.cbos.pl/SPISKOM.POL/2016/K_054_16.PDF.

Bohlouli, M., Dalter, J., Dornhöfer, M., Zenkert, J., Fathi, M. (2015). Knowledge discovery from SM using big data-provided sentiment analysis. Journal of Information Science, 41(6), 779-798.

Contraction European policies of the Law and Justice (2017). Stefan Batory Foundation. Retrieved September 11, 2018, from http://www.batory.org.pl/upload/files/pdf/W\%20zwarciu\%20-\%20 polityka\%20europejska\%20rzadu\%20PiS_raport\%20Fundacji\%20Batorego.pdf.

Ćwiek-Karpowicz, M. (2006). Opinia publiczna o obawach i nadziejach wobec Rosji i Niemiec. Retrieved June 15, 2018, from https://www.isp.org.pl/pl/publikacje/opinia-publiczna-o-obawachi-nadziejach-wobec-rosji-i-niemiec-komunikat-z-badan-isp.

Dąbrowski, M. (2009). Deconstruction of Polishness and Germaness. Rudnicki and Załuski. Comparisons, 6, 211-224.

Diez-Nicolas, J. (2009). Some theoretical and methodological applications of centre-periphery theory and the social position index. In K. van der Veer (Ed.), Multidimensional Social Science (pp. 44-71). Amsterdam: Rozenberg.

Ganowicz, E. (2016). The German minority in local politics - the case of Opole and Silesia. Polish Borderlands Studies, 4(2), 247-261.

Harrington, S. (2014). Tweeting about the telly: Live TV, audiences, and social media. In K. Weller (Ed.), Twitter and Society (pp. 237-247). New York: Peter Lang.

Hess, A., \& Szymańska, A. (2014). National Minorities in Media. Krakow: Wydawnictwo Uniwersytetu Jagiellońskiego.

Keib, K., \& Wojdynski, B. (2018). TV News Facebook Posts, Perceived Credibility, and Engagement Intent. Retrieved September 11, 2018, from https://journals.sagepub.com/doi/10.1177/193124 3118767733.

Kofta, M., \& Jasińska-Kania, A. (Eds.) (2001). Stereotypes and Prejudices. Psychological and Cultural Determinants. Warsaw: Scholar.

Kurcz, I. (2008). Language of stereotypes. Psychological Colloquia, 8, 27-39.

Łokić, P. (2014). Activity of Polish journalists on Twitter. e-Politikon, 12, 126-149.

Matelski, M., \& Sakson, A. (2000). The 10th anniversary of the national policy of the Republic of Poland towards the German minority. Humanities Review, 5, 71-80.

Matelski, M. (2017). The Polish-German reconciliation in 1934-1939 and 1989-2015. Similarities and differences. Journalism Research Review Quarterly, 2, 23-39. 
Mudde, C. (2004). The populist Zeitgeist. Government and Opposition, 39, 541-563.

Navar-Gill, A. (2017). From strategic retweets to group hangs: Writers' room Twitter accounts and the productive ecology of TV social media fans. Television \& New Media, 5, 415-430.

Nowicka, M. (2010). The comparative analysis of the media image of nation and state - a case of weeklies "Der Spiegel" and "Polityka". Media - Culture - Society, 1(5), 73-96.

Ociepka, B., \& Łada, A. (2009). Image of Polish and German European policy during tensions a comparative analysis of Polish and German press. Media Studies, 1(36), 11-28.

Olechowska, P. (2015). The role and significance of the media in shaping the image of the PolishGerman borderlands in the 1990s. Acta Universitatis Lodziensis, 2(28), 163-178.

Olechowska, P. (2017). Bridges over the Border - The Polish-German Journalist's Award 1997-2015, Szczecin: University of Szczecin Publishing.

Piontek, D. (2011). Political Communications and Popular Culture. Poznań: Adam Mickiewicz University Publishing.

Poles about II War Reparations (2017). OBOP Survey, Retrieved June 15, 2018, from http://tnsglobal. pl/archiv_files/K.072-06_Polska-Niemcy-i-Rosja_O11a-06.pdf.

Polish-German Relationship (2016). CBOS Survey. Retrieved June 15, 2018, from https://www.cbos. pl/SPISKOM.POL/2016/K_088_16.PDF.

Realo, A., Allik, J., Lonnqvist, J. E., Verkasalo, M., Kwiatkowska, A., Kööts, L., \& Renge, V. (2009). Mechanisms of the national stereotype: How people in six neighbouring countries of Russia describe themselves and the typical Russian. European Journal of Personality, 23, 229-249.

Röger, M. (2009). Anti-German policy or a newspaper representing German interests? German publisher and publications in the "Fakt" tabloid. Media Studies, 1(36), 28-45.

Rooduijn M., de Lange S. L., \& van der Brug W. (2014). A populist Zeitgeist. Party Politics, 20(4), 563-575.

Rosicki, R., \& Rosicki, G. (2012). Importance of the Nord Stream gas pipeline for Poland. CJSH, 4(6), $139-156$.

Sparks, C. (2000). The panic over tabloid news. In C. Sparks \& J. Tulloch (Eds.), Tabloid Tales (pp. 1-40). Lanham, Md.: Rowman \& Littlefield.

Terracciano, A., Abdel-Khalek, A. M., Ádám, N., Adamovová, L., Ahn, C. K., Ahn, H.-N., \& McCrae, R. R. (2005). National character does not reflect mean personality trait levels in 49 cultures. Science, 310, 96-100.

Trimithiotis, D. (2017). Understanding political discourses about Europe: A multilevel contextual approach to discourse. Discourse \& Society, 29(2), 160-179.

Trzcielińska-Polus, A. (2016). Evolution of the role of the German minority in Poland and Polonia in Germany in the Polish-German relations at the end of the 20th century and beginning of 21st. Krakow International Studies, 13(2), 23-41.

Van Dijk, T. A. (2006). Discourse, context, and cognition. Discourse Studies, 8(1), 159-177.

Van Dijk, T. A. (2009). Society in Discourse: How Context Controls Text and Talk. Cambridge: Cambridge University Press.

Wąsicka-Sroczyńska M. (2019). Polish Parliamentary Parties Attitudes Towards the National Broadcasting Council and Public Broadcasters. Poznań: Adam Mickiewicz University Publishing.

Węglińska, A. (2018). Journalists of Public Television in Poland - Between Politics, Remit and the Market. Wrocław: Dolnośląska Szkoła Wyższa.

Wolf-Powęska, A. (2004). The distance partnership - Poland-Germany. Science, 4, 49-64.

World War II in the Memory of Poles: 75 years after the German Attack (2014). TNS Polska Survey. Retrieved June 15, 2018, from http://www.tnsglobal.pl/archiwumraportow/files/2014/09/K.059_ II-wojna_swiatowa_w_pamieci_Polakow_O08a-14.pdf.

Wóycicki, K., \& Czachór, W. (2009). How to Talk with Germans. Wrocław: Atut.

Zygadlewicz, M. (2016). Relationship between German social Policy and migration crisis. Catallaxy, $1(1), 17-29$. 